\title{
Review
}

\section{Politik Üyeliğin “Öteki” Yüzü: Mülteciler, Sığınmacılar, Göçmenler ve Yabancılar}

Abdül Samet Çelikçi ${ }^{a}$

Ötekilerin Hakları: Yabancılar, Yerliler, Vatandaşlar

Seyla Benhabib

Istanbul, 2014, Iletişim Yayınları, 242 sayfa

Dünya genelinde bilhassa da Orta Doğu coğrafyasında göçmen, mülteci, sığınmacı, yabancı veya daha genel anlamı ile öteki olmanın bedeli çoğu zaman oldukça ağır olmaktadır. Öteki olmaktan kaynaklı oluşan trajik tablo ise her geçen gün biraz daha yakıcı hâle gelmektedir. Seyla Benhabib'in verili ulus devletler sistemi içerisindeki egemen devletlerin göçmenlere, sığınmacılara, mültecilere ve yabancılara dönük politikalarını ve uygulamalarını vatandaşlık (politik üyelik) kavramının sınırlarını zorlayarak tartıştı̆̆ bu kitabı, son dönemde ortaya çıkan trajik tablonun bir nebze olsun iyileştirilebilmesi için oldukça zihin açıcı bir nitelik taşımaktadır.

Benhabib, beş bölümden oluşan kitabının birinci bölümünde (s. 35-57), Immanuel Kant'ın Kozmopolit Hak kavramının yeniden bir okumasını yapmaktadır. Bu bölüm dâhilinde yazar yabancılara dönük olan, Kant'ın konukseverlik ve geçici ikamet olarak tanımladığı hakları ele almakta ve bunu bir kalkış noktası yaparak geçici ikamet hakkı sahibinin politik üyelik hakkına evrensel ahlaksallık bağlamında bir insan hakkı olarak yaklaşılması gerekliliğini tartışmaktadır. Yazar ikinci bölümde (s. 59-79), Hannah Arendt'in haklara sahip olma hakkı ifadesinden hareketle insanllk hakkının önemini açıklamaktadır. Bu bölümde yazar, ulusal egemenlik ve evrensel insan hakları arasındaki gerilimi tartışma konusu yaparak ulus devletler sisteminin çelişkilerini ortaya koymaya çalışmaktadır. Ulus devletlerce yaratılan sığınmacılar, azınlıklar, uyruksuzlar ve

a $(\triangle)$ Muş Alparslan Üniversitesi, Siyaset Bilimi ve Kamu Yönetimi Bölümü, Merkez 49250 Muş Elektronik posta: sametcelikci@hotmail.com \& as.celikci@alparslan.edu.tr

Başvuru: 30 Ağustos 2015

Kabul: 1 Ekim 2015

OnlineFirst: 13 Kasım 2015
Copyright @ 2016 • Uluslararası Mülteci Hakları Derneği • http://mejrs.com

DOI 10.12738/mejrs.2016.1.1.R0001 • Bahar 2016 • 1(1) • 125-127 
yersiz yurtsuzlar gibi insan kategorilerinin sorunlarının ancak evrensel insan haklarının geniş biçimde uygulanması ile çözülebileceğini savunmaktadır. Yazar, göç hareketleri üzerine yoğunlaştığı üçüncü bölümde (s. 81-138) John Rawls'ın kapalı toplum modelinin eleştirel bir tartışmasını yapmaktadır. Bu çerçevede de devletlerin katı göç ve göçmen politikalarını eleştiren yazar, bu bölümde liberal demokrasilerde sınırların geçirgenliğinin ülkeler için bir tehdit değil aksine demokratik açıdan bir zenginlik olduğu görüşünü savunmaktadır. Dördüncü bölümde (s. 139-177) vatandaşlık kavramının geçirdiği dönüşümleri inceleyen yazar, vatandaşlık kavramını temel insan hakları ile ilintili bir biçimde ele almakta ve ayrıca pratik olarak Avrupa Birliği vatandaşlığını incelemektedir. Bu doğrultuda vatandaşlığa kabule hiçbir şekilde izin verilmemesini veya bunun çeşitli nedenlerle kısıtlanması gibi uygulamaları üyeliğe ilişkin insan hakkı ihlali olarak değerlendirmektedir. Yazar, kitabının beşinci ve son bölümünde (s. 179-219) demokratik yineleme kavramına odaklanmaktadır. Fransa ve Almanya'da gerçekleşen ve yabancılara dönük hak sınırlandırmalarının (başörtüsü ile okula girme, başörtüsü ile ders verme ve uzun süreli yabancı mukimlerin oy kullanma haklarının yasaklanması gibi) yaşandığı üç ayrı olay ve bu olayların çözüme kavuşturulması üzerinden demokratik yinelemeler sürecinin önemini ortaya koymaktadır.

Benhabib, kitabına uluslar ötesi göçlerin liberal demokrasilerin yapısal ikilemini ortaya koyduğunu tespit ederek başlamaktadır. Bu ikilem, bir yanda egemen ulus devletlerin özbelirlenim iddiaları ve diğer yanda ise evrensel insan haklarına bağllllk ilkesinin yaratmış olduğu ikilemdir (s. 12). Bu noktada, kendi önerisinin ne devletin sonu ne de dünya vatandaşlığı olduğunu ve Kantçı kozmopolit federalizm geleneği izlediğini ifade eden yazar, üyelik sorunlarına adil dağıtım eksenli çözüm arayan yeni Kantçı teorilerden farklı olarak, adil üyelik odaklı bir yaklaşım geliştirmeye çalışmaktadır. Yazara göre, adil üyelik "mültecilerin ve sığınmacıların ilk kabul için yaptıkları ahlaki talebin tanınması; göçmenler için geçirgen bir sınır rejimi; ulusal haklardan mahrum etme ve vatandaşlık haklarının kaybına karşı ihtiyati tedbir; her insanın 'hakka sahip olma', yani, tüzel kişi olma hakkının korunması" gibi temel hakları içermektedir. Bu haklar, politik üyelik statülerine bakılmaksızın, geri alınamaz bir nitelik taşımakla birlikte, adil üyelik, belirli şartları karşılayan yabancılara vatandaşlık hakkının verilmesini gerektirmektedir. Ayrıca, daimi olarak vatandaşlıktan çıkarma uygulamasının, liberal demokratik bir insan topluluğu kavrayışıyla uyuşmadığını belirten yazar, bunun temel bir hakkın ihlali olduğunu vurgulamaktadır (s. 13-14).

Öte yandan, yazar, kitap boyunca göçmenler, mülteciler, sığınmacılar ve yabancıların hukuki statüleri ve vatandaşlık haklarına ilişkin Kant'ın kozmopolit federalizminden Arendt'in haklara sahip olma hakkına ve Rawls'in halkların yasasına kadar oldukça önemli felsefi ve teorik tartışmalar yürütmektedir. Bu felsefi ve teorik tartışmalar zaman zaman okuyucuyu asıl bağlamdan uzaklaştırır gibi olsa da kitabın temel savunusu için önemli bir zemin hazırlamaktadır. 
Küreselleşmenin dünyanın her yerindeki insan topluluklarının birbirine olan bağımlılığını artırdığının, yeni temsil alanları ve dinamikleri yarattığının altına çizen yazar, toprağa bağlı ve kültürel kimlik ilişkisine dayandırılan üyelik biçimlerinin yetersiz olduğuna vurgu yapmaktadır. Buradan hareketle, kitap boyunca Kantçı bir çizgide ahlaki evrenselcilik ve kozmopolit federalizm için talepte bulunmaktadır. Merkeze liberal demokrasileri koyarak Batı merkezci bir yaklaşım içerisinde olmasına ve zaman zaman fazlasıyla teorik ve felsefi bir tartışma yürütmesine karşın Benhabib, kitap boyunca ötekilerin haklarına ilişkin oldukça önemli ve somut önerilerde bulunmaktadır. Örneğin, açık değil geçirgen sınırları savunmakta, mültecilere ve sığınma hakk1 arayanlara ilk kabul hakları uygulanmasını ve bu ilk kabulün tam üyeliğe dönüşme hakkının olmasını istemekte ve vatandaşlığa kabulü düzenleyen yasaların insan hakları ilkelerine uygun olması gerektiğini belirtmektedir. Bunun yanı sıra, egemen halkların vatandaşlığa kabule izin vermemelerine ve aralarında yaşayan yabancıların vatandaşlığının önüne hukuki birtakım engel koymalarına karşı çıkmaktadır.

Benhabib'in bu kitabında, uluslar ötesi göçler neticesinde ortaya çıkmış olan mülteci, sığınmacı, göçmen ve yabancı gibi insan kategorilerinin hukuki statülerine ve kendilerine egemen ulus devletlerce tanınan hakların yetersizliğine dikkat çekmektedir. Bunun yanı sıra, yürüttüŭü teorik ve felsefi tartışmalar ekseninde Kantçı bir çizgiden kozmopolit federalizm talebinde bulunmaktadır. Dahası, yine bu çerçevede bugün öteki olarak adlandırılan insanların mevcut hukuki statülerinin iyileştirilmesi, vatandaşlık haklarından mahrum bırakılmamaları, iltica ve sığınma haklarının düzenlenmesi ve bulundukları ülkedeki siyasal hayata katılmalarının önünün açılması gibi konuları temel insan hakları çerçevesinde ele alarak devletlerce uygulanması hiç de zor olmayan somut öneriler sunmaktadır.

Seyla Benhabib, İstanbul doğumludur. Yale ve New Haven üniversitelerinde çalışarak doktorasını 1977'de tamamlamıştır. ABD Yale Üniversitesinde profesördür. Siyaset bilimi ve felsefesi alanında çalışmaktadır. 